\title{
PEMANFAATAN LAHAN PEKARANGAN DAN LIMBAH ORGANIK TERFERMENTASI SEBAGAI BAHAN AMELIORAN UNTUK KETAHANAN PANGAN DI WILAYAH PESISIR
}

\section{Utilization of Backyard Land and Fermented Organic Waste as Ameliorant Materials For Food Security in Coastal Area}

\author{
Arsy Aysyah Anas*1), Zulfikar ${ }^{2)}$, Waode Siti Anima Hisein ${ }^{3)}$, Nini Mila Rahni ${ }^{1)}$, Mirza Arsyati \\ Arsyad $^{1)}$, Agustono Slamet ${ }^{4)}$, La Mudi ${ }^{1)}$ \\ 1Jurusan Agroteknologi, Fakultas Pertanian, Universitas Halu Oleo, Kendari, Indonesia \\ ${ }^{2} J u r u s a n$ Ilmu Tanah, Fakultas Pertanian, Universitas Halu Oleo, Kendari, Indonesia \\ ${ }^{3} J u r u s a n$ Proteksi Tanaman, Fakultas Pertanian, Universitas Halu Oleo, Kendari, Indonesia \\ ${ }^{4} J u r u s a n$ Agribisnis, Fakultas Pertanian, Universitas Halu Oleo, Kendari, Indonesia \\ ${ }^{*}$ Korespondensi: arsyaysyah@gmail.com
}

Diterima 15 Oktober 2020 / Disetujui 23 Desember 2020

\begin{abstract}
ABSTRAK
Wilayah pesisir merupakan interface antara kawasan laut dan darat yang saling mempengaruhi dan dipengaruhi satu sama lainnya, baik secara biogeofisik maupun sosial ekonomi. Masyarakat pesisir adalah masyarakat yang tinggal dan melakukan berbagai aktifitas ekonomi dan sosialnya berhubungan dengan wilayah pesisir dan lautan. Secara Ekonomi, masyarakat pesisir termasuk dalam golongan masyarakat dengan penghasilan rendah. Hal ini berdampak pada rendahnya daya beli masyarakat terhadap produk-produk pangan untuk pemenuhan gizi keluarga. Pemanfaatan lahan pekarangan menjadi solusi terbaik dalam membangun ketahanan pangan keluarga masyarakat pesisir. Namun, pemanfaatan lahan pekarangan di wilayah pesisir diperhadapkan pada kompleksitas masalah lingkungan utamanya tanah dan atmosfer (klimatologis) yang kurang mendukung bagi pertumbuhan tanaman. Program Kemitraan Masyarakat (PKM) ini di fokuskan pada pemberdayaan masyarakat khususnya kelompok ibu-ibu rumah tangga pesisir untuk mengadopsi teknologi pengolahan limbah organic menjadi limbah organic terfermentasi yang berfungsi sebagai bahan ameliorant tanah, yang selanjutnya dapat memperbaiki kondisi lingkungan tumbuh tanaman di lahan pekarangan. Kegiatan PKM dilaksanakan di kelurahan Talia berlangsung dari Bulan Juni hingga Oktober 2020. Pendekatan PRA (Paticipatory Rural Appraisal) yang meliputi metode sosialisasi, bimbingan teknis, penyuluhan dan pendampingan serta analisis laboratorium diterapkan untuk meningkatkan minat, motivasi, semangat, pemahaman dan pengetahuan masyarakat/kelompok lbu-lbu Rumah Tangga. Hasil kegiatan menunjukkan minat dan antusias Mitra cukup tinggi yang ditunjukkan dengan mitra telah mampu mengolah limbah organic menjadi limbah organic terfermentasi sebagai bahan ameliorant tanah secara mandiri, yang selanjutnya diaplikasikan untuk budidaya tanaman sayuran di lahan pekarangan dan hasilnya telah dimanfaatkan atau dikonsumsi.
\end{abstract}

Kata Kunci: lahan pekarangan, limbah organic terfermentasi, bahan amelioran, ketahanan pangan, wilayah pesisir. 


\section{ABSTRACT}

The coastal area is an interface between sea and land areas that influence and influenced by one another, both biogeophysical and socio-economical. Coastal communities live and carry out various economic and social activities related to coastal areas and oceans. They have been economically categorized into low-income groups that impact their low-purchasing power for food products to fulfill family nutrition. The utilization of backyard land is the best solution to building food security for coastal communities. However, yards in coastal areas face complex environmental problems, especially soil and climatology, which are less supportive of plant growth. This Community Partnership Program (PKM) focuses on empowering communities, especially groups of coastal housewives, on adopting organic waste processing technology into fermented organic waste as soil ameliorant material improving environmental conditions for growing plants in yards. PKM carried out in Subdistrict Talia from June to October 2020. The PRA (Participatory Rural Appraisal) approach, consisting of socialization methods, technical guidance, counseling and mentoring, and laboratory analysis, was applied to increase interest, motivation, enthusiasm, understanding, and community knowledge. The results showed that partners' interest and enthusiasm were relatively high. They have independently processed organic waste into fermented organic waste as a soil ameliorant and applied it into vegetable cultivation in their yards, and consumed the crops.

Keywords: backyard land, fermented organic waste, ameliorant materials, food security, coastal area

\section{PENDAHULUAN}

Wilayah pesisir merupakan interface antara kawasan laut dan darat yang saling mempengaruhi dan dipengaruhi satu sama lainnya, baik secara biogeofisik maupun sosial ekonomi.Wilayah pesisir mempunyai karakteristik yang khusus sebagai akibat interaksi antara proses-proses yang terjadi di daratan dan di lautan. Ke arah darat, wilayah pesisir meliputi bagian daratan, baik kering maupun terendam air, yang masih dipengaruhi sifat-sifat laut seperti pasang surut,anginlaut dan perembesan air asin; sedangkan ke arah laut, wilayah pesisir mencakup bagian laut yang masih dipengaruhi oleh proses-proses alami yang terjadi di darat seperti sedimentasi dan aliran air tawar, maupun yang disebabkan oleh kegiatan manusia di darat seperti penggundulan hutan dan pencemaran..

Masyarakat pesisir adalah masyarakat yang tinggal dan melakukan berbagai aktifitas ekonomi dan sosialnya berhubungan dengan wilayah pesisir dan lautan. Sehingga masyarakat pesisir identik dengan masyarakat nelayan. Berdasarkan data BPS (2018), 57 \% penduduk di Kelurahan Talia bermata pencaharian sebagai nelayan. Secara umum pendapatan nelayan selalu berfluktuasi dari hari ke hari, tergantung pada musim. Terkadang dalam suatu hari, mereka dapat memperoleh tangkapan yang banyak (pendapatan besar), namun di hari lainnya tidak (tidak ada pendapatan). Hal ini berdampak pada tingkat kesejahteran masyarakat pesisir lebih rendah dan digolongkan sebagai masyarakat miskin. Dari segi ketahanan pangan, kondisi demikian secara langsung 
akan mempengaruhi kemampuan masyarakat dalam mengakses/menyediakan bahan pangan untuk memenuhi kebutuhan keluarga. Usaha yang dapat dilakukan, yaitu dengan membangun ketahanan pangan berbasis keluarga melalui pemanfaatan lahan pekarangan.

Lahan pekarangan adalah suatu area/lahan yang berada di sekitar rumah dan jelas kepemilikannya, batas fisik pekarangan seperti tembok, pagar besi, pagar tanaman, gundukan tanah, parit, patok, tonggak batu, atau tanaman. Pemanfaatan pekarangan rumah di wilayah mitra diperhadapkan pada kondisi lahan yang tergolong sebagai lahan marginal. Lahan pasir pesisir merupakan lahan dengan produktivitas rendah karena adanya beberapa faktor pembatas, diantaranya kemampuan menyangga dan menyimpan air rendah, infiltrasi dan evaporasi tinggi, kesuburan dan bahan organic sangat rendah dan efisiensi penggunaan air rendah (Kertonegoro,2001; Al- Omran, et al., 2004). Lebih lanjut, Syukur (2005) menjelaskan bahwa lahan pasir pantai juga memiliki kemampuan menyediakan udara yang berlebihan, sehingga mempercepat pengeringan dan oksidasi bahan organik. Di samping itu, lahan pasir pantai merupakan lahan marginal kedua setelah tanah masam yang lempung, debu, dan zat hara yang sangat minim. Akibatnya, tanah pasir mudah mengalirkan air, sebaliknya, kemampuan tanah pasir menyimpan air sangat rendah, dari total air yang tersedia. Kecepatan angin di wilayah pantai juga berpotensi untuk mencabut akar dan merobohkan tanaman, dan bisa membawa partikel- partikel garam yang dapat mengganggu pertumbuhan tanaman. Suhu di kawasan pantai siang hari sangat panas. Ini menyebabkan proses kehilangan air tanah akibat proses penguapan sangat tinggi (Prapto dkk.,2000).

Salah satu alternative teknologi untuk memanfaatkan lahan pasir pesisir di pekarangan rumah adalah dengan memanfaatkan limbah organic terfermentasi sebagai bahan amelioran. Bahan ameliorant atau pembenah tanah adalah bahan-bahan sintetis atau alami, organik atau mineral, berbentuk padat maupun cair, mampu memperbaiki struktur tanah, dapat merubah kapasitas tanah menahan dan melalukan air, serta dapat memperbaiki kemampuan tanah memegang unsur hara, sehingga unsur hara tidak mudah hilang, dan tanaman masih mampu memanfaatkannya. Suriadikarta et al., (2005) dan Rachman et al.,(2006) menjelaskan bahwa bahan pembenah tanah merupakan suatu bahan yang dapat digunakan untuk mempercepat pemulihan/ perbaikan kualitas tanah. Salah satu bahan pembenah tanah yang dapat digunakan adalah limbah organic terfermentasi. Limbah organic merupakan salah satu sumber bahan organic pada tanah.Hasil dekomposisi bahan organic berupa hara makro ( $\mathrm{N}, \mathrm{P}$, danK), makro sekunder ( $\mathrm{Ca}, \mathrm{Mg}$, dan $\mathrm{S}$ ) serta hara mikro yang dapat meningkatkan kesuburan tanaman (Kasno,2008). Menurut Stevenson (1982), bahan organik tanah merupakan salah satu bahan pembentuk agregat tanah, yang mempunyai peran sebagai bahan perekatan antar partikel tanah untuk bersatu menjadi agregat tanah. Limbah organic yang dapat dimanfaatkan sebagai bahan ameliorant tanah yang banyak tersedia dan tidak termanfaatkan di sekitar wilayah mitra antara lain kotoran ternak (sapi dan kambing), gamal dan komba-komba (krinyuh). 
Program PKM ini ditujukan untuk memberdayaan masyarakat khususnya kelompok ibu-ibu rumah tangga di wilayah pesisir untuk mengadopsi teknologi rekayasa tanah dan atmosfer lahan pesisir melalui pemanfaatan limbah organic terfermentasi sebagai bahan ameliorant tanah untuk ketahanan pangan dan gizi keluarga

\section{METODE KEGIATAN}

Program Kemitraan Masyarakat (PKM) ini dilaksanakan pada Bulan Juni - Oktober 2020 di Kelurahan Talia, Kecamatan Abeli, Kota Kendari, Sulawesi Tenggara. Pelaksanaan program ini menggunakan pendekatan PRA (Paticipatory Rural Appraisal) meliputi metode sosialisasi, bimbingan teknis, penyuluhan dan pendampingan serta analisis laboratorium. Metode-metode tersebut diterapkan untuk meningkatkan minat, motivasi, semangat, pemahaman dan pengetahuan masyarakat/kelompok lbu-lbu Rumah Tangga (SDM). Berdasarkan studi awal tim pelaksana, maka dirumuskan kegiatankegiatan berikut untuk menyelesaikan permasalahan-permasalahan prioritas di wilayah mitra, yaitu:

1). Pemberian pemahaman kepada

kelompok ibu-ibu rumah tangga pesisir tentang karakteristik lahan pesisir dan pentingnya pemanfaatan lahan pekarangan dalam menciptakan ketahanan pangan dan peningkatan gizi keluarga

2). Sosialisasi/introduksi pengenalan limbahlimbah organic di lingkungan mitra yang berpotensi diolah menjadi limbah organik terfermentasi sebagai bahan ameliorant tanah sekaligus bentuk teknologi sederhana yang efektif,efisien,murah dan ramah lingkungan.

3). Sosialisasi/demonstrasi budidaya tanaman sayuran pada lahan pekarangan rumah

4). Bimbingan teknis dan pelatihan cara pengelolaan limbah organic menjadi limbah organic terfermentasi sebagai bahan ameliorant tanah pesisir.

5). Diseminasi dan pembuatan model/demplot budidaya sayuran dengan pendampingan yang intensif

6). Meningkatkan minat, motivasi dan semangat ibu-ibu rumah tangga dalam memanfaatkan lahan pekarangannya sebagai tempat memproduksi bahan pangan, dalam rangka menciptakan ketahanan pangankeluarganya

7). Meningkatkan kesejahteraan masyarakat pesisir melalui pemangkasan biaya belanja utamanya untuk kebutuhan sayur-sayuran

8). terciptanya peluang lapangan kerja baru atau usaha

Pelaksanaan kegiatan dievaluasi oleh pihak internal perguruan tinggi dalam hal ini oleh LPPM Universitas Halu Oleo dan pihak eksternal dari DRPM Ditjen Penguatan Risbang Kemenristek Dikti melalui mekanisme pelaporan, seminar hasil dan target luaran pelaksanaan program. Untuk keberlanjutan program, tim pelaksana akan terus menjalin kerjasama dengan mitra dengan melakukan penguatan kelembagaan kelompok ibu-ibu rumah tangga peisisr dengan selalu membuka ruang konsultasi dan pendampingan. Tim pelaksana juga melibatkan mahasiswa dalam pelaksanaan program untuk lebih mengintensifkan pendampingan dan keberlanjutan program melalui kegiatan penelitian mahasiswa. 


\section{HASIL DAN PEMBAHASAN}

Tahapan-tahapan kegiatan Program Kemitraan Masyarakat (PKM) dilaksanakan pada masa pandemic Covid-19. Penerapan protocol kesehatan yang ketat baik oleh mitra maupun tim pelaksana, meliputi penggunaan masker termasuk face shield, hand sanitizer, dan jaga jarak. Hasil kegiatan PKM yang telah dicapai ditampilkan secara lengkap pada Tabel dan Gambar-Gambar berikut.

Tabel 1. Jenis kegiatan dan hasil yang telah dicapai selama pelaksanaan kegiatan PKM di Kelurahan Talia

\begin{tabular}{|c|c|c|}
\hline No & Jenis Kegiatan & Keluaran \\
\hline \multirow[t]{3}{*}{1} & & Pelaksanaan PKM telah mendapatkan izin dari Universitas \\
\hline & & $\begin{array}{l}\text { Halu Oleo dalam hal ini kepala Lembaga Pengabdian } \\
\text { kepada Masyarakat (LPPM) dan Rektor Universitas Halu }\end{array}$ \\
\hline & Pengurusan izin pengabdian & Oleo. \\
\hline 2. & Observasi/Survey wilayah/lokasi Kegiatan & $\begin{array}{l}\text { Survey/obesrvasi yang ditujuakn untuk mengumpulkan } \\
\text { informasi terkait wilayah/lokasi kegiatan telah dilakukan } \\
\text { telah dilakukan di Kelurahan Talia }\end{array}$ \\
\hline 3. & Persiapan pelaksanaan kegiatan & $\begin{array}{l}\text { Pertemuan anggota tim pelaksana dan mahasiswa tingkat } \\
\text { akhir dari Jurusan Ilmu Tanah dan Jurusan Agroteknologi }\end{array}$ \\
\hline 4. & $\begin{array}{l}\text { Sosialisasi awal program kepada } \\
\text { Pemerintah Kelurahan Talia dan Mitra } \\
\text { (Ketua Kelompok Ibu-Ibu Rumah Tangga) }\end{array}$ & $\begin{array}{l}\text { Sosialisasi kegiatan sekaligus permintaan izin untuk } \\
\text { pelaksanaan kegiatan kepada kepala kelurahan Talia telah } \\
\text { dilakukan }\end{array}$ \\
\hline 5. & $\begin{array}{l}\text { Penyuluhan tentang pemanfaatan limbah } \\
\text { organic di sekitar lingkungan masyarakat } \\
\text { berupa kotoran ternak, pangkasan gamal, } \\
\text { sampah organic rumah tangga, dan } \\
\text { tumbuhan liar (komba-komba) }\end{array}$ & $\begin{array}{l}\text { Penyuluhan telah dilaksanakan dan dihadiri oleh Kepala } \\
\text { Kelurahan Talia, dan Ketua RW/RT }\end{array}$ \\
\hline 6. & $\begin{array}{l}\text { Sosialisasi tentang bahan ameliorant } \\
\text { tanah sebagai teknologi peningkatan } \\
\text { kemampuan tanah di wilayah pesisir } \\
\text { dalam mendukung pertumbuhan tanaman } \\
\text { kepada mitra }\end{array}$ & $\begin{array}{l}\text { Kegiatan sosialisasi telah dilaksanakan dan dihadiri oleh } \\
\text { Kepala Kelurahan Talia, dan Ketua RW/RT }\end{array}$ \\
\hline 7. & $\begin{array}{l}\text { Demonstrasi dan bimbingan teknis cara } \\
\text { pengolahan limbah organic menjadi } \\
\text { limbah organic terfermentasi yang akan } \\
\text { digunakan sebagai bahan ameliorant } \\
\text { tanah }\end{array}$ & $\begin{array}{l}\text { Kegiatan demonstrasi dan bimbingan teknis telah } \\
\text { dilakukan yang diikuti oleh seluruh peserta }\end{array}$ \\
\hline 8 & $\begin{array}{l}\text { Pembuatan bahan ameliorant berupa } \\
\text { limbah organic terfermentasi yang siap } \\
\text { pakai }\end{array}$ & $\begin{array}{l}\text { Limbah organic terfermentasi telah berhasil dibuat dan } \\
\text { telah diaplikasikan pada lahan pekarangan mitra }\end{array}$ \\
\hline 9. & $\begin{array}{l}\text { Pembuatan demplot untuk pengaplikasian } \\
\text { limbah organic terfermentasi sebagai } \\
\text { bahan amelioran pada lahan pekarang } \\
\text { milik mitra }\end{array}$ & $\begin{array}{l}\text { Demplot untuk pengaplikasian limbah organic } \\
\text { terfermentasi sebagai bahan ameliorant telah dilakukan. } \\
\text { Total demplot berjumlah 8, terdiri atas demplot berupa } \\
\text { rak susun untuk polybag tanaman berjumlah } 7 \text { dan } 1 \\
\text { demplot berupa lahan }\end{array}$ \\
\hline 10. & $\begin{array}{l}\text { Bimbingan teknis dan demonstrasi aplikasi } \\
\text { limbah organic terfermentasi sebagai }\end{array}$ & $\begin{array}{l}\text { Aplikasi/pemberian bahan ameliorant berupa limbah } \\
\text { organic terfermentasi telah dilaksanakan yang diawali }\end{array}$ \\
\hline
\end{tabular}




\begin{tabular}{lll}
\hline \hline bahan ameliorant langsung pada masing- & dengan memberikan informasi dan bimbingan langsung \\
masing demplot & tentang jumlah/dosis dan cara pengaplikasian bahan \\
& & $\begin{array}{l}\text { ameliorant baik yang diterapkan pada polybag maupun } \\
\text { lahan, }\end{array}$ \\
\hline 11 & Pembibitan beberapa benih tanaman & Benih sayuran yang dibibitkan berupa tomat, terong ungu, \\
& sayuran & cabai merah, sawi, pakcoy. Sedangkan bayam merah, \\
& & bayam hijau, kangkong dan kacang Panjang ditanam
\end{tabular}

Beberapa Gambar tentang tahapan-

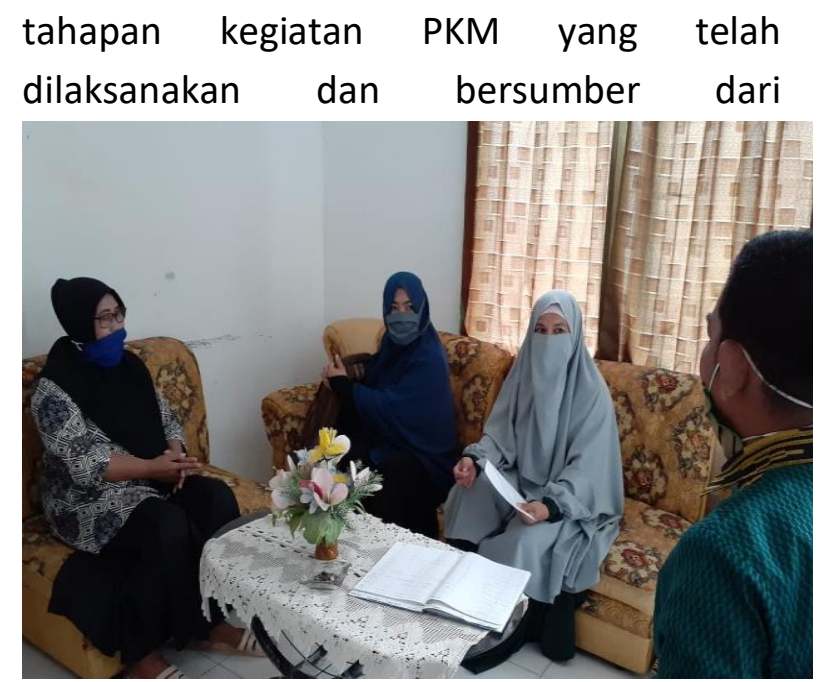

Gambar 1. Pengurusan surat izin kegiatan di Kantor Kelurahan Talia

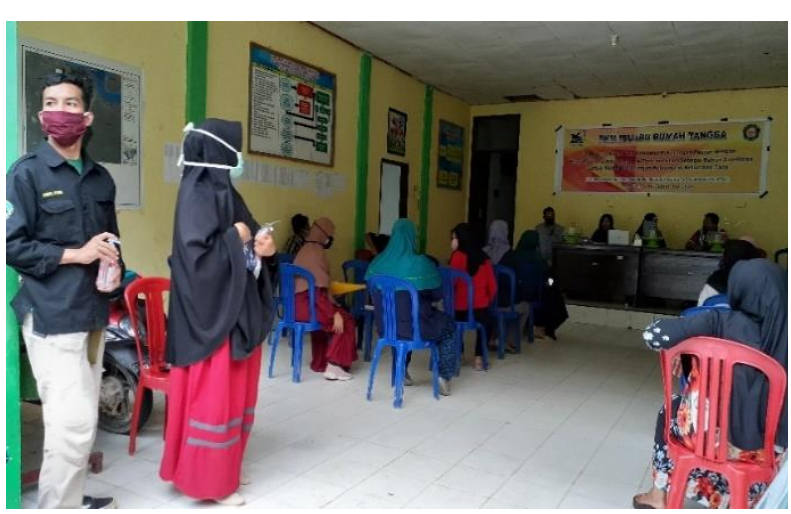

Gambar 3. Kegiatan Sosialisasi Kelurahan dokumentasi tim pelaksana dan mitra (2020).

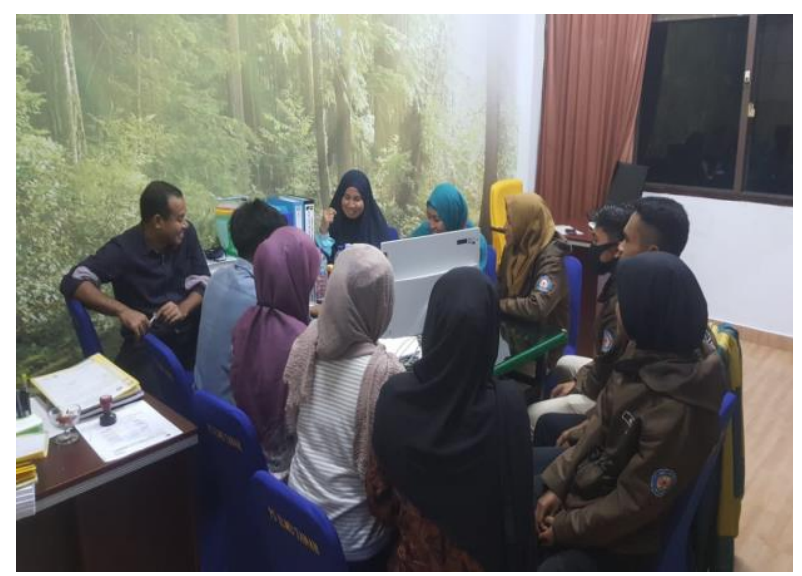

Gambar 2. Rapat persiapan pelaksanaan sosialisasi dan demonstrasi kegiatan antara Tim pelaksana dan Mahasiswa yang akan terlibat

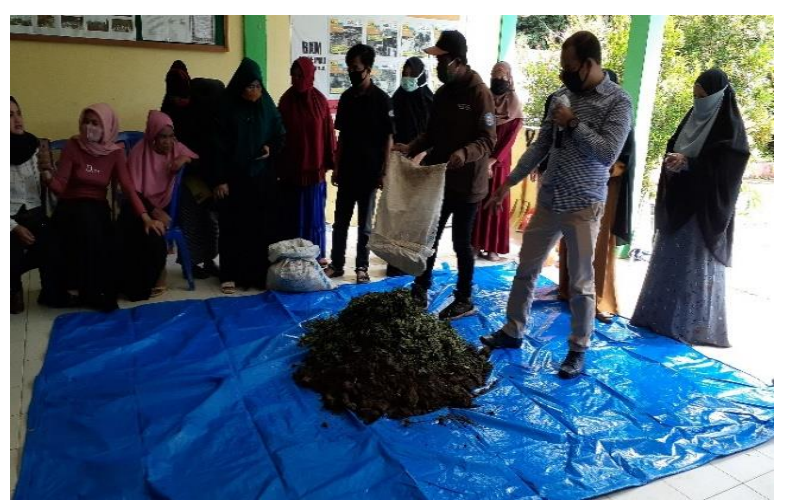

Gambar 4. Demonstrasi pembuatan limbah 


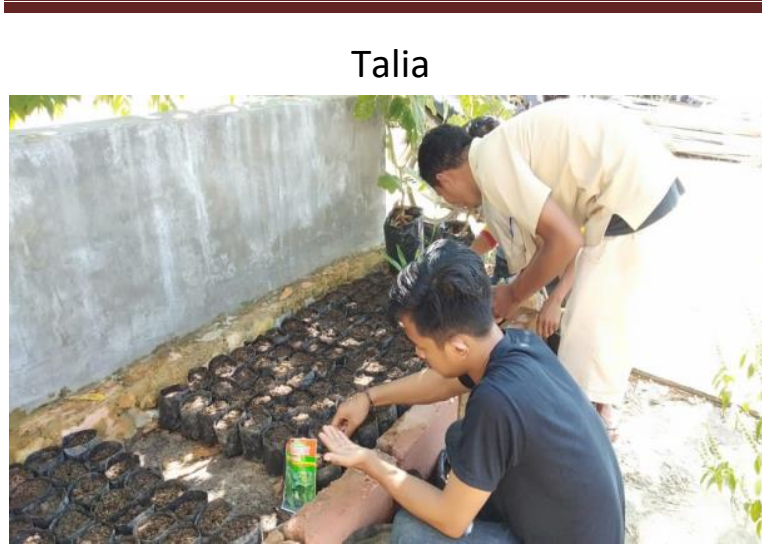

Gambar 5. Pembibitan

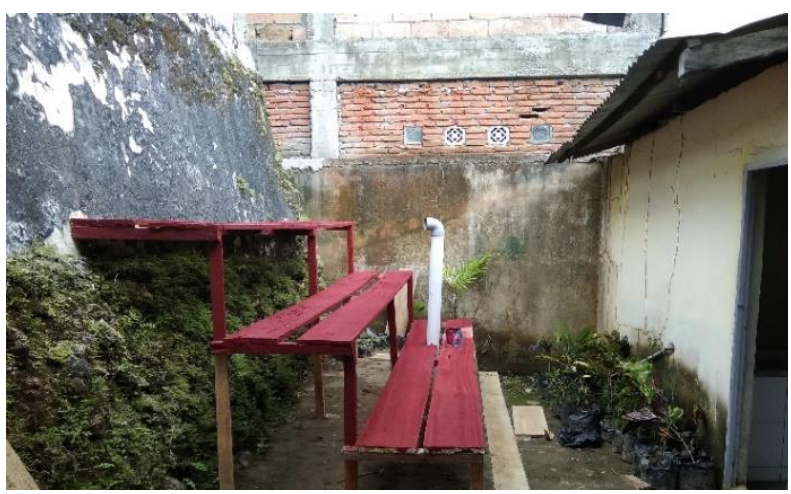

Gambar 7. Model demplot rak

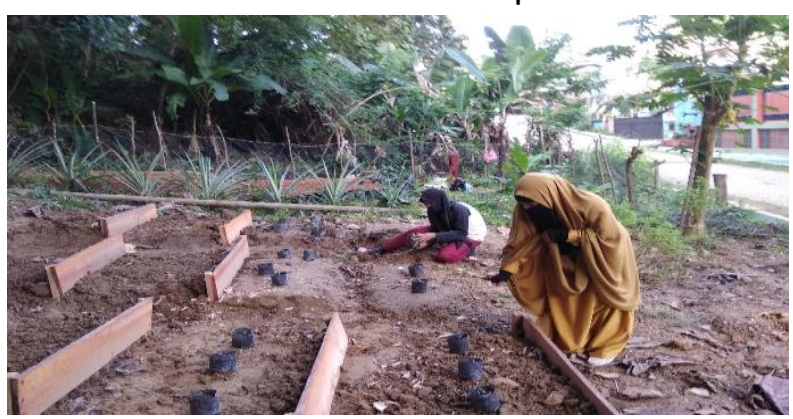

Gambar 9. Penanaman di demplot lahan organic terfermentasi

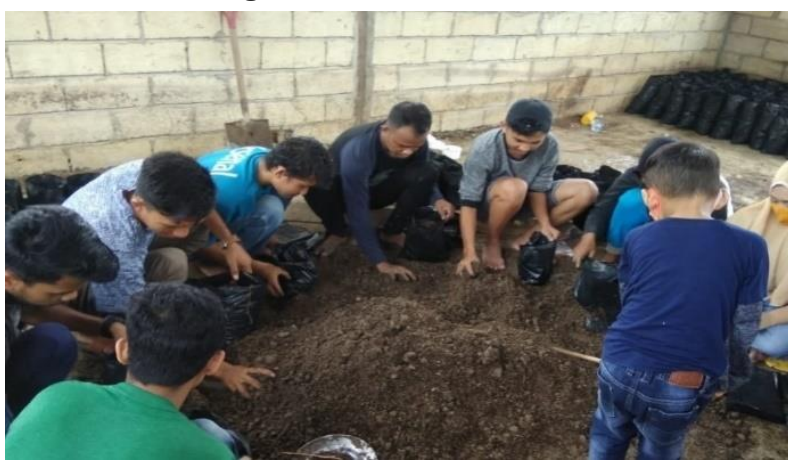

Gambar 6. Pengisian media tanam

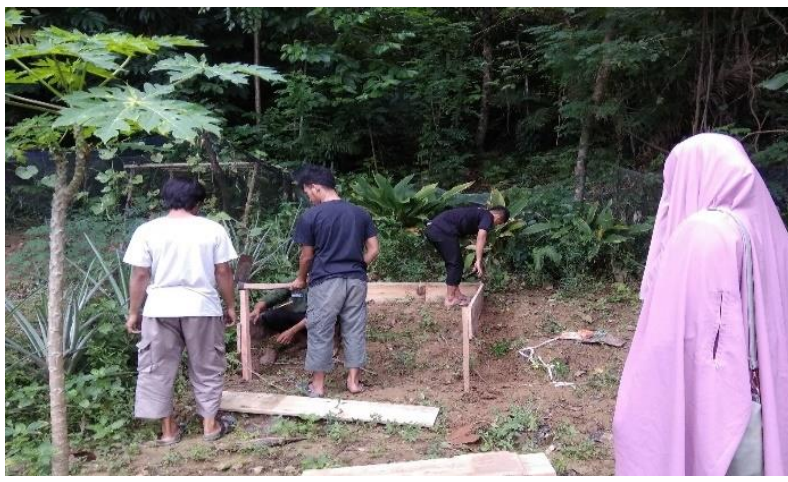

Gambar 8. Demplot Lahan

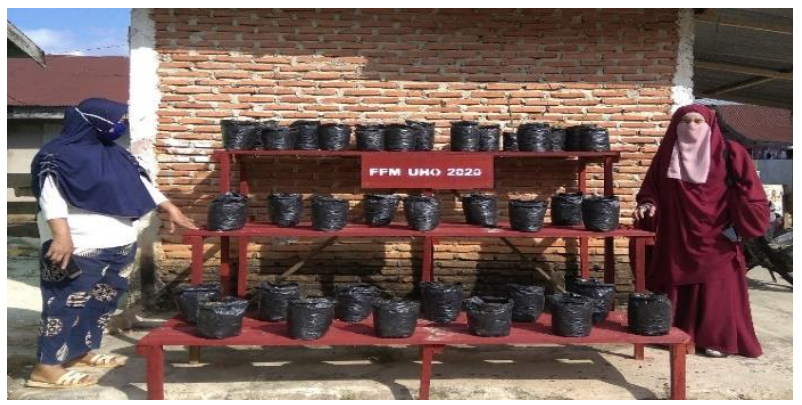

Gambar 10. Polybag sayurandi demplot rak
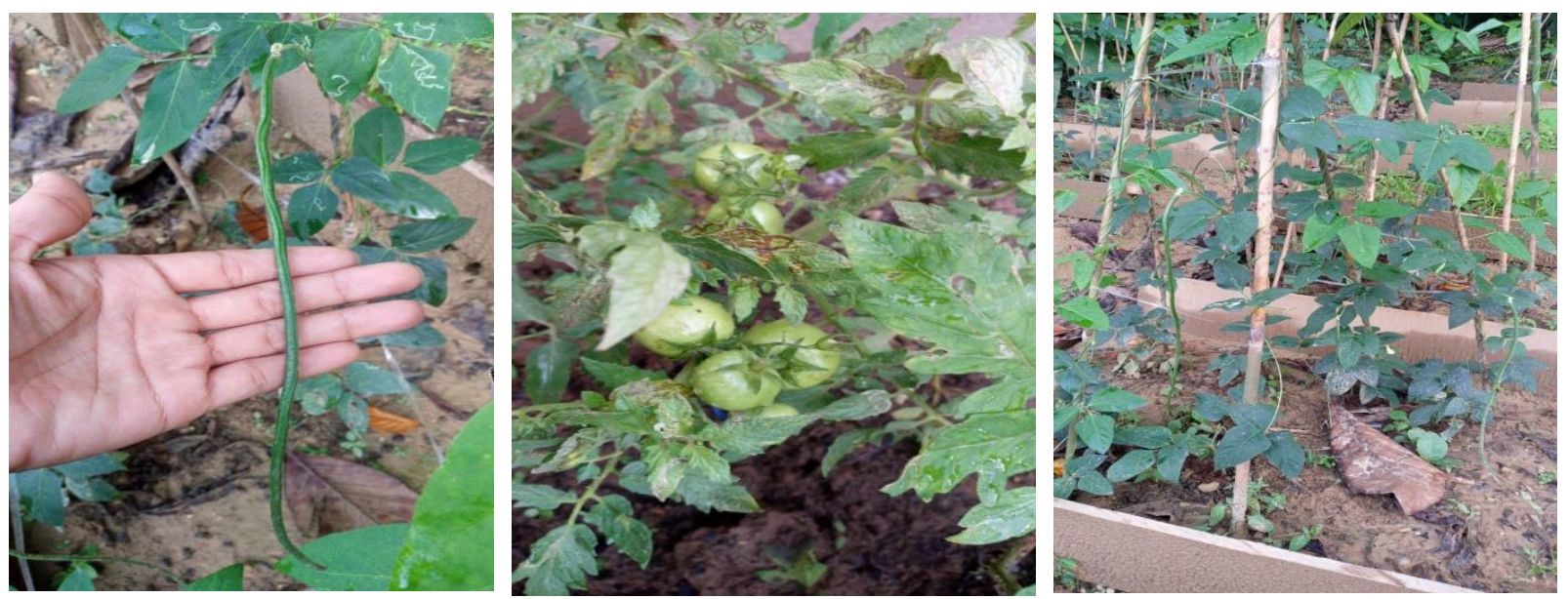

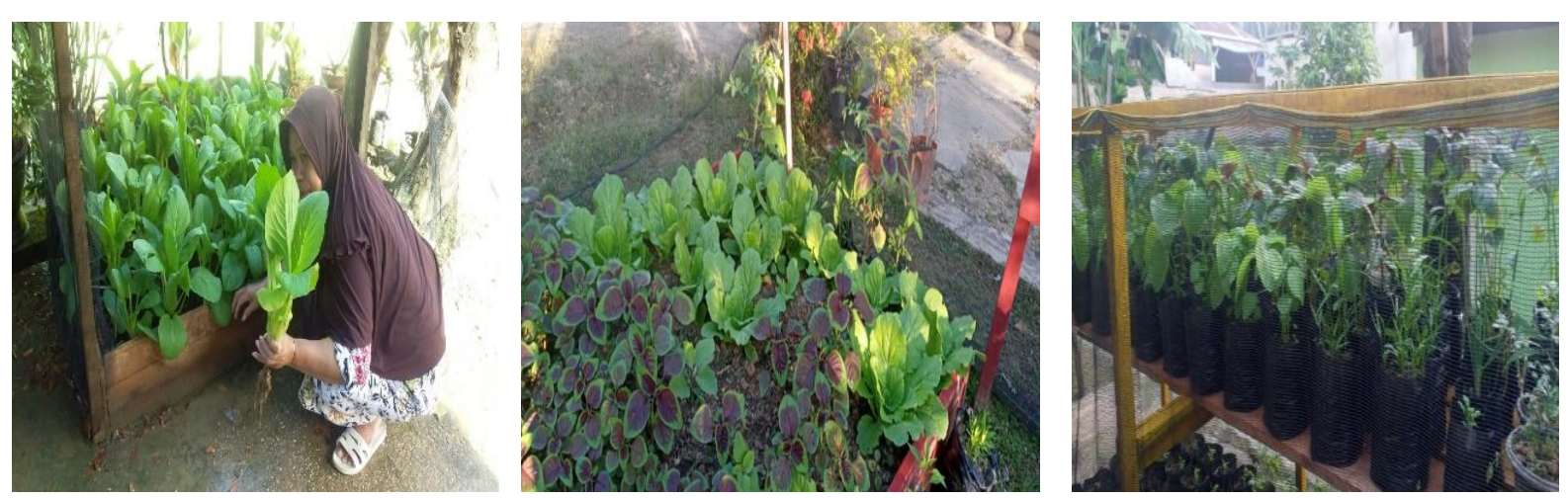

Gambar 11. Pertumbuhan tanaman pada demplot lahan dan rak

Tahapan pelaksanaan PKM ini juga telah dipublikasikan melalui media online Panji Kendari pada tanggal 24 Juni 2020. Artikel lengkap dapat diakses https://panjikendari.com/memanfaatkanpekarangan-untuk-meningkatkan-

ketahanan-pangan-keluarga-di-wilayah-

pesisir-di-kota-kendari/. Produk yang dihasilkan dalam program ini berupa produk bahan ameliorant tanah siap pakai.

\section{KESIMPULAN DAN SARAN}

\section{A. Kesimpulan}

Pengembangan lahan pekarangan di wilayah mitra sebagai salah satu usaha dalam membangun ketahanan pangan keluarga sangat dimungkinkan melalui pemanfaatan limbah organic terfermentasi sebagai bahan ameliorant. Pada wilayah mitra bahan baku berupa limbah organic seperti kotoran ternak baik sapi, kambing dan ayam sangat melimpah, demikian pula dengan tanaman gamal yang banyak dijadikan sebagai tanaman pagar, dan komba-komba yang tumbuh liar pada pinggiran jalan ataupun dalam areal lahan yang tidak termanfaatkan. Disamping itu, teknologi pembuatan bahan ameliorant sangat sederhana, mudah dan murah sehingga dapat dilakukan baik secara mandiri maupun berkelompok. Peluang peningkatan pendapatan melalui budidaya tanaman sayuran di lahan pekarangan sangat besar, sebab lokasi mitra berdekatan dengan pusat wisata yang sedang berkembang termasuk wisata kuliner local. Salah satu kuliner local yang banyak dicari adalah sinonggi yang merupakan makanan khas Kota Kendari. Kuliner ini membutuhkan banyak sayuran segar seperti bayam, terong, lombok biji dan tomat sebagai bahan lauk utama bersama ikan parende. Di sisi lain, adanya pandemic Covid-19 yang membuat masyarakat takut untuk banyak melakukan aktifitas kegiatan di luar rumah dan berinteraksi dengan banyak orang termasuk belanja ke pasar, menjadi peluang usaha untuk mengkomersilkan tanaman sayuran yang dibudidayakan di pekarangan rumah.

\section{B. SARAN}

Pendampingan mitra secara intensif harus terus dipertahankan, agar semangat dan motifasi mitra tetap besar dalam mengadopsi teknologi pengolahan limbah organic menjadi limbah organic terfermentasi sebagai bahan ameliorant, guna pengembangan lahan pekarangan untuk ketahanan pangan keluarga, sekaligus menjadi peluang usaha baru yang dapat meningkatkan pendapatan dan kesejahteraan mitra. 


\section{UCAPAN TERIMA KASIH}

Terima Kasih kepada Direktorat Riset dan Pengabdian pada Masyarakat (DRPM) Direktorat Jenderal Penguatan Riset dan Pengembangan Kementerian Riset, Teknologi, dan Pendidikan Tinggi yang telah mendanai kegiatan PKM ini. Terima Kasih kepada Lembaga Penelitian dan Pengabdian Kepada Masyarakat UHO atas kerjasamanya. Dan terima kasih kepada pemerintah dan masyarakat Kelurahan Talia khususnya kelompok Ibu-lbu Rumah Tangga Pesisir yang menjadi mitra kegiatan, rekan-rekan tim pelaksana dan mahasiswa-mahasiswa yang ikut terlibat aktif membantu pelaksanaan kegiatan PKM ini. Semoga Allah SWT membalas dengan pahala yang berlimpah. Aamiin.

\section{DAFTAR PUSTAKA}

Anas, A.A., N.M. Rahni, dan S. N. Isnian. 2019. Bioteknologi Bokashi Plus dan Intercropping pada Tanaman Hortikultura. Jurnal Inovasi Sains dan Teknologi (Instek). Vol. 1 No. 2. Februari 2019.

Anas, A.A., N.M. Rahni, dan S. N. Isnian. 2018. Pemanfaatan Vegetasi Sekunder dan Limbah Serbuk Gergaji Sebagai Pupuk Bokashi Plus Pada Budidaya Tanaman Hortikultura dalam Sistem Intercropping. Jurnal Pegabdian Masyarakat Amaliah. Vol. 2 No. 2, Desember 2018.

Andini, L. 2019. Pemanfaatan Vegetasi Sekunder Terhadap Pertumbuhan dan Produksi Terong Ungu (Solanum melongena L.) di Lahan Kering Marginal. Skripsi Fakultas
PertanianUHO.

Ashari, S., dan Purwantini, T.B. (2012). Potensi dan Prospek Pemanfaatan Lahan Pekarangan Untuk Mendukung Ketahanan Pangan. Bogor: Pusat Sosial Ekonomi dan Kebijakan Pertanian.

Dariah, A. 2017. Bahan Pembenah Tanah. Prospek dan Kendala Pemanfaatannya. Sinar Tani edisi 6 Mei 2017.Jakarta

Djatihardi, A. 2016. Optimalisasi Pemanfaatan Pekarangan Melalui M-KRPL di Kabupaten Cianjur. Prosiding Seminar Nasional Inovasi Teknologi Pertanian Banjarbaru, 20 Juli 2016. Hal.1742-1750

Dwiratna, N.P.S., Widyasanti, A., dan Rahmah, D.M. (2016). Pemanfaatan Lahan Pekarangan Dengan Menerapkan Konsep Kawasan Rumah Pangan Lestari. Jurnal Aplikasi Untuk Masyarakat Dharmakarya, 5(1):24-32.

Fadel, Muhammad. (2009). Reinventing Local Government: Pengalaman dari Daerah. Jakarta:Gramedia.

Hosen, N. 2008. Potensi dan masalah pengembangan lahan pekarangan mendukung peningkatan produksi buah-buahan di sumatera barat. Prosisding seminar hortikultura, Puslitbang Hortikultura.

Indriyani, L. dan A.A. Anas. 2015. Remediation of soil with abundance of Iron Through The Use of Sago Waste Extraction. Prosiding The 8TH International Conference on Innovation and Collaboration Towards ASEAN Community 2015.

Kasno, A. 2008. Peranan Bahan Organik 
Terhadap Kesuburan Tanah. Balai Penelitian Tanah Informasi Ringkas Bank Pengetahuan Padi Indonesia

Ma'ruf, Amar. 2018. Karakteristik Lahan Pesisir Dan Pengelolaannya Untuk Pertanian.

https://www.researchgate.net/publ ication/324830583 Karakteristik La han Pesisir_Dan_Pengelolaannya_ Untuk_Pertanian. Diakses 2 september 2019.

Putri, Fiadini. 2011. Bertani di Lahan Pasir Pantai. BBPP Lembang

Rachman, A., A. Dariah, dan D. Santoso. 2006. Pupuk Hijau. Dalam Pupuk Organik dan Pupuk Hayati. Balai Besar Sumberdaya Lahan Pertanian. Badan Penelitian dan Pengembangan Pertanian.

Rositasari, R. 2001. Indonesia Menuju Manajemen Wilayah Pesisir Terintegrasi.

http://oseanografi.lipi.go.id/dokum en/oseana xxvi(2)25-34.pdf.

Diakses 2 september 2019.
Safitri, E., Budiyono, dan N. Suwarni. 2012. Karakteristik Sosial Ekonomi Nelayan Di Kelurahan Pasar Krui Kecamatan Pesisir Tengah Kabupaten Lampung Barat.

https://media.neliti.com/media/publications /250563-karakteristik-sosialekonomi-nelayan-di-5408c4df.pdf. Diakses 2 september 2019

Sagiman, S. 2001.Peningkatan Produksi Kedelai di Tanah Gambut Melalui Inokulasi Bradyrhizobium Japonicum Asal Gambut dan Pemanfaatan Bahan Amelioran (Lumpur dan Kapur). Disertasi Program Pasca Sarjana Institute PertanianBogor

Suriadikarta, D.A., T. Prihatini, D. Setyorini, dan W. Hartatik. 2005. Teknologi pengelolaan bahan organik tanah. HIm. 169-222 Dalam Teknologi Pengelolaan Lahan Kering. Pusat Penelitian Tanah dan Agrklimat. Badan Litbang Pertanian. 